Stefan Zimmer

Rheinische Friedrich-Wilhelms Universität Bonn

s.zimmer@uni-bonn.de

\title{
ON COMPARING SLAVIC AND CELTIC THEONYMS, WITH REGARD TO THEIR INDO-EUROPEAN BACKGROUND
}

\section{Introduction}

The idea of looking for special relations between Celtic and Slavic is not obvious in Comparative Linguistics. These two branches of the IndoEuropean family are widely separated both geographically and chronologically. Celtic is attested on the Continent from about $500 \mathrm{BC}$ till perhaps $400 \mathrm{AD},{ }^{1}$ mostly in the West, whereas Slavic appears first in the second half of the $1^{\text {st }}$ millennium AD. Traditionally, the "cradle" of the Slavs is sought in a region covering parts of present-day Poland, Belorussia and Ukraine. Some scholars, however, also consider more westerly or more southernly homesteads. Anyhow, no trace of Slavic is found before the $6^{\text {th }}$ century $\mathrm{AD}$. Only then, the various tribes start to settle down in the lands they are occupying later according to historical records. Their common language, which we call "Proto-Slav(on)ic", has widely been reconstructed; it was spoken, presumably with local variants, till about $800 \mathrm{AD}$. The following period, "Common Slavic", covers the time when the various dialects differentiated into the known vernaculars. The first written form of Slavic is usually called "Old Church Slavonic" because it is the language of the Bible and other Christian texts, translated from the Greek by Constantine and Methodius between c. 863 and 885 into their native dialect of Saloniki.

Information about the culture of the Slavs in the pre-Christian period is found exclusively in non-Slavic sources; in most cases, these are German, Norse, and Greek records. Early Slavonic chronicles, first the Old Russian ones, also give some hints to older traditions. ${ }^{2}$ On the whole, what all these texts tell us is, of course, precious - but it is also of doubtful reliabilty, because, unfortunately but not unsurprisingly for the scholar, it is heavily fraugth with historical and philological problems.

\footnotetext{
${ }^{1}$ And again, of course, by Breton since about the 5th century AD.

2 The standard collection (not only of the Latin and Greek sources) is Meyer (1931).
} 
For the present purpose, viz. some linguistic comments on a few theonyms, most of this can be put aside. One should only keep in mind that some, or even most, of the small number of Old Slavonic theonyms recorded in the just mentioned sources may in fact be voces nihili, or the result of gross Mediaeval misunderstandings. The interpretation, linguistic or otherwise, of all of these names is highly disputed. ${ }^{3}$ True, the interpretation of proper names is one of the shakiest fields in linguistics, especially if clear comparanda do not exist.

\section{Earlier comparisons}

Roman Jakobson's studies on Comparative Slavic Mythology from 1950 to his death in 1982 (Jakobson 1985: 3-53) remain classical, ${ }^{4}$ even if many of his ideas would deserve, after so many years, critical assessment in the light of present day scholarship. This is impossible for me not being a Slavic scholar, and would be out of place here anyhow. Here are some comments on a few recent proposals involving comparison with Celtic material.

1.1. One such attempt has been brought forward by Polish scholars, summed up in Rosen-Przeworska (1971) and defended, with modifications, by Moszyński (1992). There, we are invited to believe that the theonym Puruvit, known from Garz on the island of Rügen is an adaptation of Celtic Bormo, allegedly a Celtic sun-god; that Turupi, from the same source, stands for *Taran-vits, a cpd. with the Celtic thunder-god's name; and that Triglav's three heads reflect Celtic deities with multiple faces.

All this is, of course, far from convincing. There are unsurmountable objections, such as the anachronistic comparison of $12^{\text {th }}$ c. records with preChristian deities from a country which was separated from Slavic speaking territory for a good millennium by speakers of a third branch of IE, viz. Germanic. Gaulish Bormo or Borvo (with unspectacular lenition) is probably a god of hot springs, but definitely not a solar deity; alleged "reconstructions" like Turupi < Taran-vitъ are incorrect; and Triglav, in case it should not be of genuine Proto-Slavic age, could easily be a Medieval formation modelled after the Christian Trinity.

1.2. Another case are the Common Slavic proper names with first member (FM) Msstb-, such as Msstb-bogъ, -borъ, -drugъ, -slavъ, -radъ, which seem to be built from an imperative 'revenge!'. Falileyev and Kazansky

${ }^{3}$ As is well known, this field is often fraught with nationalistic feelings and ideological biases.

${ }^{4}$ Cf. also Ivanov-Toporov (1965) and Toporov (1974). 
(1997), referring to Kurkina (1994), already found fault with this traditional analysis. Instead, they suggested, but unfortunately without detailed discussion, a comparison with the Gaulish lexical elements meddu- and $m e \theta \theta i$ - (Greek theta is a letter for the affricate commonly called "tau gallicum"). Their rejection of Kurkina's translations is correct. These, in fact, fail to take into account the known possible structures of Indo-European nominal compounds. Even if proper names and epithets display special features on occasion, such as the type of "reversed Bahivrîhi", these formal rules still apply. A compound with a verbal stem as FM, and a substantive as second member (SM), is a Govering compound (G Verbales Rektionskompositum), where the verb governs a direct object. So, if $\mathrm{Mbst}_{b-}$ in the names referred to were an "imperative", Mbstb-bogb should mean 'revenge the god', -slavs 'revenge the fame', etc. This is hardly acceptable for obvious semantic reasons.

Falileyev and Kazansky's proposal to interpret $M_{b s} t_{b}$ - in these compounds as an abstract noun, continuing IE *med-ti- 'the act of thinking', vel sim., is therefore much better. But their all too short statement that those names are "ultimately cognate with Greek: Mń $\delta \omega \nu$ [...] and possibly with Gaulish names in *med-" (1997: 109) does not pay sufficient attention to the proper analyzing of the Slavic compounds either. Remarkably, they give only one attempt at translation: Msstb-bors is said to mean 'choice thinker'; this, they think, "is semantically identical to Aphrodite's nickname $\Phi \iota \lambda \mathrm{o}-\mu \eta \delta \eta^{\prime} \varsigma^{\prime}$ (ibid. 110).

This falls short of various facts. First of all, an epithet like $\Phi \imath \lambda \mathrm{o}-\mu \eta \delta \dot{n} \varsigma$ is not a "nick-name". ${ }^{5}$ Second, Gaulish meddu- and me$\theta \theta i$-, abstracts from the root "med- 'to measure, to judge', may well be used as technical terms, perhaps for 'judgement' or 'opinion', but cannot be at all nomina agentis 'thinker' as Falileyev and Kazansky seem to imply. ${ }^{6}$

1.3. Václav Blažek has suggested three Celto-Slavic comparisons (in Celto-Slavica I, 75-85).

1.3.1. Following Abaev, he holds possible that Slav Dažsbogъ may be borrowed from a hypothetical CC *Dogi-devvo-, attested in OIr Dagda. This would of course have to imply, that Slav *děvs should have been identified with "divъ 'demon' and therefore, have been substituted by *bogъ.

\footnotetext{
5 "A familiar or humorous name given ... instead of or as well as the real name", according to the New Oxford Dictionary of English, 2001, 1251c.

${ }^{6}$ There is, of course, the well-known development of such an agent meaning by re-analysis of BV-cpds. CC * $\mathrm{X}$-vlatis , characterised by rule over / through $\mathrm{X}$ ' is easily taken to mean ,ruler over / through X'. This explains the double meaning of OIr flaith 'rule, ruler', which caused the formation of semantically clear flaithem 'lord'.
} 
Furthermore, instead of a FM *dogi-, a lengthened grade * ${ }^{*}$ ogi- would be required to give Slav *dažb. All of this is not only highly speculative, but quite improbable. Ir Dagda is a specific Goidelic formation; the adj. CC *dago- is an $o$-stem, not an $i$-stem. On the Slavic side, an element * děv a vox nihili, and various reshufflements of the name may be possible, but are not to be supported by known parallels.

1.3.2. Following Kalygin, he proposed to see in the female Mokoši a borrowing from CC ${ }^{*}$ Makasiā, allegedly a pre-form of the Ir mythical Macha. As clearly spelled out by Wodtko (2000: 242-2), both the meaning of CIber makasi(a)m and the etymology of Ir Macha are far from secured. ${ }^{7}$ So, Kalygin's speculation lacks the ground it is built upon.

1.3.3. Blažek's comparison of Czech Premysl (OCzech Premizl, the name of mythical rules, translated by medieval authors as 'premeditans vel superexcogitans') and Welsh Pwyll (a mythical King of Dyfed) may be correct if the etymology starting from a common preform ${ }^{*} k^{w} e y s-s l o / \bar{a}$ is accepted (cf. also Matasović 2009: 179). The standard analysis of W pwyll, Ir cíal 'sense, reason' is, however, * $k^{w}$ eys-lā (see LEIA C-94).

\section{The element $\operatorname{bog}_{\boldsymbol{b}}$ - background}

An onomastic element of relatively high frequency in early Slavic is bogъ. This word is usually translated as 'god', in accordance with its standard meaning in all modern Slavic languages. However, this is not the whole truth, as clearly shown by a few lexemes which are proof of another, older, and in fact the original meaning of the lexeme. ${ }^{8}$ Consider first these two words: bogatъ 'rich' and $u b_{b} g_{b}$ 'poor'. Both words are clearly archaisms (i.e. at least Proto-Slavic formations), the first as proven by its formation type (verbal adjective in * ${ }^{*}$ tó-from a nominal stem, not from a verbal root, with the special meaning 'provided with...'), and the second by its prefix. In Jaan Puhvel's classical formulation "The relation of bogatъ: $u$ bogъ is that of Latin barbatus: imberbus". ${ }^{9}$

7 John Carey (p.c.) suggests Macha to have been originally a place name, related to mag 'plain'. This seems to be accepted by Ó Mainnín (2009), but is rather problematic: mag 'plain' is a neuter s-stem. Cf. further DIL s.v. with several homonyms, e.g. ${ }^{1}$ macha 'milking parlour', a masculine dental stem.

${ }^{8}$ See the detailed discussion in Zimmer (1984) and in Zimmer (1986).

${ }^{9}$ Cited from KZ 73, 1956, 208 fn. 1. - The type represented by bogat乃 has lost its productivity early in various branches of IE, but is still well attested by eg. Sanskrit vyādita- 'ill, with sickness', Avestan hu-kərəpta- 'pretty, with a well-shaped figure', Greek $\dot{\alpha}-\gamma \varepsilon \dot{\varepsilon} \rho \sigma \tau$ ○ 'unrewarded, without being rewarded [from * $\gamma \varepsilon \rho \alpha \sigma \tau$ ó $\varsigma$ 'provided with a gift of honour'], Latin barbatus 'bearded', fortunatus 'happy = with fortune', honestus 'honorable, with honour', onestus 'loaden, with a heavy charge'. 
The Sl. adjective $u$-bogø 'poor', is a Bahuvrîhi compound. That it is an archaism is demonstrated by two facts:

The preposition $u<{ }^{*} a w$ - 'off' is well-attested in Slavic and Baltic as shown by OCS $u$-daliti 'to remove', $u$-myti 'to clean, lit. to wash away', $\mathrm{Ru}$ у-бежать 'to run away', (arch. and dialectal) y-брус 'wipe-cloth', у-спение 'passing away, death' (: спать schlafen, cf. dt. ent-schlafen); Old Pruss au-mūsnan 'washing (down)', Lith (eastern) âu-monion (adverb) 'unconsciously', Latv au-manis 'senseless, furious', a place name $\mathrm{Au}$ dziras ('Drink-less', i.e. 'dry place') and to a lesser degree in some other IE languages also, ${ }^{10}$ but has lost its productivity in Slavic nominal composition very early; Slavic $u$ - retained two functions: it continues to be used as a preposition 'at'11 and has become productive as a verbal prefix used to create perfect aspect counterparts to simple imperfect verbs (type Russian видеть увидеть 'to see', слышать услышать 'to hear', жалить ужалить 'to sting, bite' совершенствовать усовершенствовать 'to perfectionate').

In nominal compounds, this old $u$ - was soon replaced by $n e$ - as in OCS $n e-b_{b}$ 'poor, wretched, miserable', and this $n e$ - is productive till the present day (ORu $u$-bogъ has been extended in ModRu to $u$-bogij which is synonymous with ne-bogij).

Besides from the old formation $u$-bog $g_{b}$ for 'poor', a Proto-Slavic “ $s_{b}-b_{b} g_{b}$ 'well equipped with share(s)' must have existed, because its (equally unattested) derivative *sъ-bоžьje is continued by Byelorussian збожье, 'grain, property', Czech zboži 'property, fortune', Polish zboże and Ukrainian

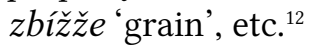

This, together with the Indo-Iranian relatives, establishes beyond any doubt that the original meaning of Slavic "bog $b$ was 'share, possession'.

The second meaning 'god' was presumably taken over from Iranian, as is taken for granted since long. It is only fair to say that some scholars have defended the inherited character of Slavic ${ }^{*} \operatorname{bog}_{b}$ with both meanings,

${ }^{10}$ Hitt $h u$-(according to H. Eichner MSS 31, 1973, 55); Lat au-fero, au-fugio, perhaps ō-tium; Greek $\alpha$ uै- $\tau \omega \varsigma$ 'in this very manner', $\alpha$ ' $\sigma$ los 'idle, vain' (Ibykos), but not $\alpha \dot{v}-\chi \alpha \dot{\alpha} \tau \tau \varepsilon \nu$ 'to come/bring back' (Hesychius) which is to be emended to $\alpha \mathcal{\nu}-\chi \alpha \dot{\alpha} \tau \varepsilon v \nu$ according to $\mathrm{K}$. Strunk (in: O-o-pe-ro-si Fs. E. Risch 1986, 269, cf. also 257sq.).

${ }^{11}$ For the semantics of 'away' and 'at' of one single word, cf. similar developments elsewhere: In Celtic, Irish gen 'without' is etymologically identical with Welsh gan 'with'. The basic meaning, in both branches, must have been 'besides', 'separate but not far from', vel sim. And Lat sine 'without' is probably comparable to Greek oúv 'with'. All this will soon be found in detail in G. Dunkel's forthcoming Lexikon indogermanischer Partikel und Präpositionen.

${ }_{12}$ More is to be found in Mayrhofer (1986-2001) and Vasmer (1976-1980). 
'share' and 'god'. Compelling arguments, however, have not been brought to the fore.

If Proto-Slavic * bog $b$ is a genuine Slavic word at all, i.e. inherited from IE, it meant only 'share', perhaps already 'possession, riches'. The same semantic shift is to be observed in India, where bhága- in post-Vedic times further developed into 'happiness, fortune'. But it may even be possible, as Schlerath (1986 and especially 2002) seems to prefer, that *bogъ had been borrowed from Iranian speaking neighbours with the double, specifically, Iranian meaning 'share' and 'god'. I cannot go into further details of the Iranian and Indian sides here.

Old Persian baga-is the standard word for god, etymologically identical with the Vedic Āditya Bhága- (m) 'Share personified' (cf. bhága- 'share') and it must have been current among Iranian tribes roving in the steppes north of the Black Sea. There, contacts with Proto- or Early Slavs were possible; one of the borrowings was this new meaning for an old and genuinely Slavic word. Hitherto, no reason was found how and why this could have happened.

Here is a new proposal:

Slavic shares with Indo-Iranian the old formation ${ }^{*}{ }^{*} b-b o g b$ 'well equipped with share(s)' just mentioned. The Slavic compound is etymologically identical with Sanskit su-bhága-, Avestan hu-baya- 'well equipped with share(s)', later 'rich, happy'. ${ }^{13}$ One cannot reconstruct with certainty a PIE ${ }^{*} h_{1} s u-b^{h} a ́ g-o$ - because a third attestation in a non-contingent language (required by Meillet's famous rule of thumb) is lacking. However, we can be sure to have here a very old formation before us, most probably coined before the complete separation of the forerunners of Indo-Iranian and Slavic.

In India, the developement of Vedic bhága- 'share' to the god Bhága(m), of mitra- (n) 'contract' to Mitra- 'Contract personified', and (following Thieme) of "váruna- 'true word' to Váruna- 'True word personified' was the central idea of the Āditya religion. These deities are all personifications of abstract principles. In Iran, the oldest attestations of baga- are to be found in Avestan: the word occurs once in the Old Avestan Gathas, and about ten times in Younger Avestan texts. Unfortunately, the only Gathic attestation remains unclear: gāuš baga $x^{v}$ arəmnō in Y 32,8, said of Yima, has been understood as to mean 'the bull declared himself a god' (so M. Schwartz, Fs. H.P. Schmidt 2003, 218) or 'the bull was eaten according to

${ }^{13}$ This is twice mentioned in Vasmer (1976-80: I 446), but without precise semantics or further discussion. 
share' (after B. Schlerath). ${ }^{14}$ In the Younger Avesta, baya- is an epithet of Ahura Mazdā, of the Moon, and of MiOra. This seems to imply, that all gods can be invoked to spend a 'share', to grant riches. Between this stage and the Achaemenid practice to use baga- exclusively as a general term for 'god' - no trace of the old 'share' is to be found in the OPers inscriptions - a further generalization must have taken place. The compound $h u^{-}$ baya- is used in Younger Avestan texts as an epithet for women, mostly deities or mythological beings. The (Proto-)Slavs, sharing already this adjective 'well provided with shares' > 'rich, happy', may have been able, in remarking the Iranian usage of baga- as 'god', to identify the two simple lexemes as well. They took over the Iranian meaning as an additional for their old word *bogъ. Perhaps, a pious re-interpretation of the compound $u$-bogb was instrumental: 'poor' < 'without shares' could be understood as 'poor' < 'away from god' in the pre-Christian period, or in the contrary, after learning about the Christian god who according to the missionaries loves the poor, as allegedly meaning 'near/with god'. At this stage, a new word for 'poor' was coined, viz. ne-bogz. A similar process may, of course, be assumed for bogatъ. Be that as it may, the retention of a few old pre-Christian formations with the old meaning 'share, riches' is remarkable. For the interpretation of Slavic theonyms, this older meaning must be taken into full consideration.

The Iranian origin of the semantic shift of the word bogъ from 'share' to 'god' is strengethend by the fact that a parallel development has taken place which cannot be motivated without a still more specific Iranian influence. This shift is to be found in Slavic divs 'evil godhead, demon', vel sim., formally going back to PIE *deywo- 'god'. Such an extraordinary semantic change hardly happened independently from Iranian, where * daiwa- was relegated by the so-called Zarathushtrian Reform to the evil sphere (MP $d \bar{e} v$, NP $d \bar{\imath} v$, etc.). Khotanese $d y \bar{u}$ is a precious attestation for the same shift outside Zoroastrian Iran, in the Buddhist east. ${ }^{15}$

\section{Old Slavonic theonyms}

Only a few old Slavic theonyms are attested. According to the sources already mentioned, they may be listed here:

\footnotetext{
${ }_{14}$ All other proposals may be safely left aside; cf. Kellens and Pirart (1988-91) who refuse to translate the passage (I 120) and speak of "obscurité" (III 87).

${ }^{15}$ See further Schlerath (2002).
} 
The old Russian Nestor's Chronicle mentions (s.a. 907/971) two names:

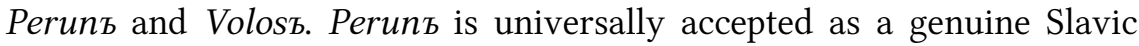
name, related to Lith Perkūnas 'oak-god, thunder-god'. Any other relation proposed is more or less doubtful: we know nothing about Thracian Perkōn (cited by Duridanov 1985: 70, 81 as an epithet). Gamkrelidze-Ivanov (527f., 694f.) add Hith Pirwa, name of a god on horseback (cf. Hekur Pirwa 'Pirwa mountain'), Skt Parvata and Parjanya, ONorse Fjörgyn (a giantess, mother of Porr), Goth faírguni 'mountain', and even (without indication of a source) an alleged Kafiri Pärun 'war god'. The latter is most likely a vox nihili. Hith Pirwa and Skt Parvata- belong to parvan- 'knot, joint', and further to Greek $\pi \varepsilon \tilde{\rho} \rho \alpha \rho, \pi \varepsilon i \rho \alpha \tau o \varsigma$ 'frontier', a typical $r / n$-heterocliticon for body parts. Fjörgyn and faírguni may belong to a PIE word for 'tree, oak' but this is far from certain. The Vedic Parjánya- is first of all a god of rain, not of thunder. The medial $-j$ - excludes comparison with the Baltic names having $-k$ - All this is of no help. Slavic Perun Perkunas, but that is all. Peruns probably is based on the root "per- 'to hit', attested in Baltic, Slavic, and Armenian (cf. LIV).

Volosb is East-Slavic for Vlass, most likely a back-formation to Vlasii < Greek Blásios. There is an alleged variant * veless in ORu Velesovs vnuče 'grandchild of Veles' in Igor's Song. But as South Slavic attestations suggest, Veless is rather an independent, genuine Slavonic formation; it is used in toponymy (as a place name in Macedonia; more often in microtoponymy) ${ }^{16}$ and may refer to watery places. Etymological proposals linking it to the root *wel- 'to see' (see e.g. Jakobson 1985:40) fail to convince. Non liquet.

The so-called Glosses of Malalas ( $10^{\text {th }}$ or $11^{\text {th }} \mathrm{c}$.?) have been used by the author of the $3^{\text {rd }}$ redaction of the Nestor Chronicle (dated 1118) for the names Svarogъ 'Hephaistos' and Dažbbogъ 'Helios'. Both names occur elsewhere later. They are genuine, but their interpretationes Graecae are not very helpful, because no pertaining mythology has been preserved. As shown by the literature listed in Vasmer (1976-80), no convincing etymology has as yet been proposed. If it is derived from svarb 'answer' (cf. $\mathrm{Ru}$ сва́pa 'dispute, strife'), the suffix - ogъ remains singular. If it is a compound with $\operatorname{rog}_{b}$ 'horn', the beginning of the word remains obscure. Only as a learned guess, one might take it as a haplological form of ${ }^{*}$ Svara-rog ${ }_{b}$ whitch could express a meaning such as 'being a horn in verbal strife' - admittedly not a very alluring explication for the name of a fire deity.

Some of the Names from ancient Polabia, transmitted by German and Norse sources of the $10^{\text {th }}$ and $11^{\text {th }} \mathrm{c}$., are more promising:

${ }^{16}$ R. Matasović and D. Brozović, p.c. 
farovit (Gerovit), Porovit (Puruvit, Porevithus), Radogost (Redigost), Svarožic (Zuarasiz, Zuarasici), Sventovit (Zvanthevith, Sventevith), Tiarnoglovy (Tjarnaglofi), Triglav (Latinised Triglaus, genitives Trigelawi, Trigalavi).

Svarožic is a diminutive form of Svarogъ already mentioned. Sventovit is a cpd. of Slav svęnts 'holy' (another loan from Iranian, perhaps) and the name of St. Vitus, taken over and incorporated just as Blasius already mentioned. The element - vit also occurs in farovit and Porovit whose first members may be *jarovb, an adjective belonging to *jars "springtime, beginning of the year' (: Av yāra, E year, etc.) and the prefix pra- or even, with haplology, the adjective pravs 'true'.

Tiarnoglovy either belongs to OCS tьrnъ or trъnъ (both forms are attested) 'brambles, thornbush', or, if Skandinavian $T j$ - may be taken as reflect-

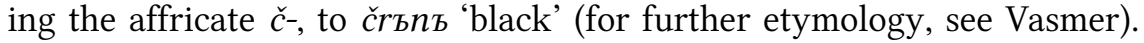
The latter is more attractive in view of the popular figure called Cornebog vel sim. in Slavic folklore.

Only one single name remains as sufficiently transparent, viz. Triglav. This cannot be anything else than 'Three-head', meaning a figure with either three heads, or in the light of preserved monuments, one head with three faces. And here, we have finally a sound comparison with Celtic, at least in specie. That only double-headed Celtic sculptures have been found on the continent (Nesactium/Istria; Holzgerlingen; Roquepertuse; cf. also the tricephalic deity on the vase of Bavay) may be explained by the obviously strong Roman influence which knows of double-faced Ianus only. Ireland preserves one specimen of a tricephalic stone (Corleck, Co. Cavan) and one of a double-busted "idol" (Boa Island, Co. Fermanagh). And there is the well-known figure on the Gundestrup cauldron, often referred to in Celtic mythological studies, but of course, of doubtful origin (Kaul \& Warmind 1999).

It should be kept in mind, however, that the Slavic pantheon represented by all these names mentioned is hardly old. Most likely, the Polabians did the same thing as the Skandinavians in Norway when they felt the influence and mounting pressure of the Christian mission: They developed a theology of their own, i.e. they elaborated their traditions in order to be able to compete with the Christian message by showing a pantheon and a mythology of their own. Unfortunately, no Slavic Edda ever was committed to parchment, or survived the Christian zeal.

To sum up: There is only one Slavic theonym which compares semantically with Celtic. Formal comparison is of course always possible in the 
framework of Comparative IE grammar, especially in word-formation. There is hardly anything like a privileged Slavo-Celtic relation. IranoSlavica would be a more promising field for comparison indeed. ${ }^{17}$

\section{References}

BlažeK, VÁClav, 2006: Celto-Slavic Parallels in Mythology and Sacral Lexicon. In: Parallels between Celtic and Slavic. (= Proceeding Celto-Slavica I 2005), ed. by S. Mac Mathúna and M. Fomin. Coleraine: Graham \& Heslip, 2006, $75-85$.

Duridanov, Ivan V., 1985: Sprache der Thraker. Neuried: Hieronymus.

Falileyev, Alexander; Kazansky, Nikolas, 1997: PIE *med- in Personal Names. IF 102, 1997, 108-111.

Ivanov, VuaČeslav Fs.; Toporov, Vladimir N., 1965: Slavjanskie jazykovye modelirujuščie semiotičeskie sistemy, Moskva: Nauka.

JAKOBSON, Roman, 1985: Selected Writings, vol. VII, ed. by Stephen Rudy, with a preface by Linda R. Waugh. Berlin-New York-Amsterdam: Mouton.

KaUl, F.; Warmind M., Gundestrup. Reallexikon der Germanischen Altertumskunde, Band 13, hrg. v. H. Beck u.a., Berlin: de Gruyter, 195-213.

KuRKINA, L.V.; TrubačËv, OlEg N., 1994: L.V. Kurkina in Oleg N. Trubačëv, ed., Ėtimologičeskij slovar'slavjanskich jazykov. Moskva: Nauka 1974- (ongoing), s.v. "mbsti-. (From vol. 23 ed. by Anatolij F. Žuravlëv).

Loma, AleKSANDR, 2000: Skythische Lehnwörter im Slavischen. Versuch einer Problemstellung. Studia Etymologica Bruniensia 1, 334-350.

Matasović, RanKo, 2009: Etymological Dictionary of Proto-Celtic. Leiden-Boston: Brill.

LEIA: Lexique étymologique de l'irlandais ancien, ed. par J. Vendryes, E. Bachellery et P.-Y. Lambert. Paris-Dublin: CNRS-DIAS. Vol. C 1987.

LIV: Helmut Rix u.a., Lexikon der indogermanischen Verben. 2. Auflage. Wiesbaden: Reichert 2001.

MAYRHOFER, MANFRED, 1986-2001: Etymologisches Wörterbuch des Altindoarischen. 3 Bde. Heidelberg: Winter.

MeYer, 1931: Fontes Historiae Religionis Slavicae, collegit Carolus Henricus Meyer. Berolini: apud W. de Gruyter 1931 (= Fontes Historiae Religionum auctoribus Graecis et Latinis collectos edidit Carolus Clemen, Fasciculus IV).

MosZYŃSKI, LesZEK, 1992: Die vorchristliche Religion der Slaven im Lichte der slavischen Sprachwissenschaft. Köln-Weimar-Wien: Böhlau.

${ }^{17}$ See e.g. Loma (2000). 
Ó Mainnín, MícheÁl, 2009: Co mBeith a Ainm Asa: The Eponymous Macha in the Place-names Mag Macha, Emain Macha and Óenach Macha. In: Ulidia 2, Proceedings of the 2nd International Conference on the Ulster Cycle of Tales, Maynooth 2005, ed. by R. Ó hUiginn and B. Ó Catháin, Maigh Nuad: An Sagart, 195-207.

Rosen-Przeworska, Janina, 1971: Religie Celtów. Warszawa: VLG.

SchleRATH, Bernfried, 1986: Baga. In: Götter und Mythen der kaukasischen und iranischen Völker, hrg. v. H.W. Haussig u.a. = Wörterbuch der Mythologie, hrg. v. H.W. Haussig, I. Abteilung, Band 4. Stuttgart: Klett-Cotta 1986, 305-306.

SCHLERATH, 2002: Iranisch und Balto-Slavisch. KZ 114, 2002, 285-289.

Toporov, V. N., 1974: Issledovanija v oblasti slavjanskych drevnostej. Moskva: Nauka.

VASMER, MAX, 1976-1980: Russisches etymologisches Wörterbuch. 3 Bde. 2. Aufl. Heidelberg: Winter.

WodtKo, S. Dagmar, 2000: Wörterbuch der keltiberischen Inschriften (= Monumenta Linguarum Hispanicarum, hrg. v. J. Untermann, Bd. V.1). Wiesbaden: Reichert.

Zimmer, Stefan, 1984: Iranisch baga- - ein Gottesname?. MSS 43, 1984, 187215.

Zimmer, Stefan, 1986: Slavisch ubogъ und 'Winter's Law'. MSS 47, 1986, $223-$ 227.

\title{
Usporedba slavenskih i keltskih teonima i njihova indoeuropska pozadina
}

\begin{abstract}
Sažetak
$\mathrm{Na}$ početku ovog rada spomenut ćemo neke novije usporedbe slavenskih i keltskih teonima, a zatim ćemo razmotriti leksički element bogz, središnji element u slavenskoj teonimiji. Na kraju ćemo dati kratak popis starih slavenskih teonima i njihove moguće lingvističke interpretacije. Pravila indoeuropske imenske tvorbe ključna su za ovaj pristup i omogućavaju nam da slavenska imena pridružimo indoeuropskoj tradiciji.
\end{abstract}

Ključne riječi: teonimi, iranski utjecaj, $b_{b}$

Key words: theonyms, Iranian influence, $b_{0} b$ 
